\title{
Study on the Perfection of Chinese Land Trust*
}

\author{
Chaoyin $\mathrm{Yu}$ \\ School of Law \\ Shandong University of Finance and Economics \\ Ji'nan, China
}

\begin{abstract}
Chinese land trust models all have defects which result in peasants contributing their right to land contractual management but not benefitting fully from the increased agricultural production that ensues. They are not precisely settlors under existing land trust models so they are not able to exercise many control rights normally available to trust settlors. Nor are they exactly the beneficiaries so they do not get the full economic benefit from the rights they contribute. The key challenge for Chinese land trusts are that trustee can't easily negotiate with individual peasants and that the land trusts models cannot easily negotiate with individual peasants. "Unit trust" or similar models may be an avenue to avoid the transaction cost difficulties, an approach that does indeed seem promising.
\end{abstract}

\section{Keywords—land trust; settlor; trustee; beneficiary}

\section{INTRODUCTION}

Since the beginning of the 21st century, land trusts have emerged in the circulation of farmland in various regions of China, in the course of which various models of land trusts come into being. The Chinese land trusts have been a hot topic in the academic circle with increasing attentions given to them.

The theme of this essay is to find some methods to improve the Chinese land trusts by analysis of their mechanism. Part II represents the three typical models of land trusts that operate in various parts of China. Part III tries a legal analysis of the land trusts from the standpoints of settlor, trustee and beneficiary of the land trusts, points out the shortcomings and unreasonableness in the operation in the land trust. Part IV discusses how to improve the operation of Chinese land trust.

\section{The Status QuO OF LAND TRUST IN CHINA}

From the beginning of 21st century, various kinds of land trusts began to appear in some areas of China, which could be classified as "Shaoxing Model", "Liuyang Model" and "Zhongxin Model".

*Project: This article is sponsored by the Planning Project of Shandong Social Science Fund of 2019 entitled The Modernization of Trust Law of China (Project Approval Number: 19BYSJ 07), Overseas Research Program for Outstanding Young Teachers of Shandong University of Finance and Economics and R\&Y Capital Market Legal Research Center of Shandong University of Finance and Economics.

\section{A. "Shaoxing Model" Land Trust}

Shaoxing, a city in located in the east part of China, was said to be the first one to use trust mechanism to facilitate the transfer of right to the contracted management land. ${ }^{1}$

In 2001 Shaoxing adopted trust mechanism in the transfer of right to land contractual management (hereafter "right to LCM") creatively. The process includes the following stages. First, the peasants who would like to transfer their rights to LCM lease the rights to the village economic co-operative. Then the co-operative trusts the leased lands to the trust agents of town after rearrangement and optimization of the lands. In the third step of the process, the trust agent of the town organizes the leaser, the cooperatives and leasees, some individuals who are good at agricultural management to sign land lease, under which the leasees engage in agricultural activities on the leased lands, such as planting crops or vegetables, and pay the rent at end of each year. ${ }^{2}$

In this model, the legal relationships involved are complicated. The lease of right to LCM binds the peasants and the village economic co-operative in the first stage. The trust contract signed between the village economic cooperative and trust agent enumerates the rights and duties of parties for the second step of the process. The last contract made between the village economic co-operative and big leasees accomplishes the whole process and make up the main body of the program.

\section{B. "Yiyang Model" Land Trust}

"Yiyang Model" land trust, sometimes called "Caowei Model", came into being in 2010 in Yiyang, a city in Hubei Province, located in the central part of China.

The peasants who intend to transfer their rights LCM conclude a trust agreement with Land Trust Corporation which was established by the local government. The Land Trust Corporation leases the trusted lands to the large leasees for agricultural purposes and at the beginning of each year LCM by Farmland Trust, Journal of Northwest A \& F University (Social Science Edition), vol. 16, No. 1, 21, 21

2 Shaoxin Fiscal Bureau, Shaoxin County Actively Explore the Mechanism of Land Trust, Rural Finance and Accountant, vol. 9, (2001), 14. 
collects the rents which will be distributed to peasants transferring rights to LCM as beneficiary. ${ }^{3}$

In this type of land trust, the legal relationship seems much simpler compared to the "Shaoxing Model". The firsttier legal relationship, trust relationship exists between the peasants transferring right to LCM and the trust corporation, in which the trust corporation would take over the rights on the lands and would be responsible for the management of land and income distribution to the peasant. The second-tier legal relationship adjusts the lease between Trust Corporation and leasees. ${ }^{4}$

\section{C. "Zhongxin Model" Land Trust}

"Zhongxin Model" land trust has a professional trust corporation $^{5}$ playing the role of trustee. The establishment of this type land trust involves the following procedure. First, sublet agreement of right to LCM is concluded between the village committee and the peasants who will transfer their rights to LCM. Secondly, the village committee makes an Agreement of Entrusting Management of Land with borough government. Thirdly, being the settlor and beneficiary of the trust, the borough government makes a trust agreement with CITIC Trust Co. Ltd (hereafter CITIC Trust). Finally, the CITIC Trust leases the trusted lands to another company or entity to manage and cultivate the lands. ${ }^{6}$

\section{LEGAL ANALYSIS OF LAND TRUST IN CHINA}

\section{A. Settlor}

Except in Yiyang Model, the peasants who transfer their rights to LCM could not take the status of settlor in the trust. The reason is obvious, because the trustee hesitates to conclude contract with individual peasants for the high cost of negotiation. At the same time, peasants have so little knowledge of trust that they don't know what settlor in the trust means to them.

The rights of peasants on the farmlands changed dramatically in the year of 2016. From 1980s, the ownership of farmland belongs to rural economic collective organization (hereafter "RECO") and member peasants enjoy the rights to LCM. In order to facilitate the circulation of farmland, the two "General Offices" ${ }^{7}$ issued the Opinions on

Hu Nengcan, Investigation on Farmland Trust Circulation of "Yiyang Mode" - Practice and Exploration on Farmland Trust Circulation of "Yiyang Mode" in Hunan, Land \& Resource Herald, 2 of vol. 12, 49.

Ye Peng. Development Process and Trend of Farmland Trust Transfer in China, Journal of Northwest A\&F University (Social Science Edition), Vol. 16 No. 1(2016), 22

Professional Trust Corporation in China refers those companies which are established under Trust Law of People's Republic of China and Measures for the Administration of Trust Companies, the trust agents in "Shaoxin" model and land Trust Corporation in "Yiyang" model are not professional trust companies established under former Trust Law and Measures.

6 Research Group of People's Bank of China Suzhou Sub-branch. Research on the Model of Circulating Trust of Farmland, Financial Perspective Journal, 2015(01), 90.

The General Office of the CPC (Communist Party of China) Central Committee and the General Office of the State Council.
Improving the Measures for Dividing into Ownership, Contracting Right and Management Right in Rural Land (the "Opinions"). According to the "Opinions", the right to LCM is divided into contracting right and the management right. In the age of "two rights division" 8 the trust property is the right to LCM while in the age of "three rights division" 9 the trust property changes to management right. The right to LCM or land management right is possessed by peasants.

The most unreasonable part in Chinese land trust is that trust property originates from the peasants' rights to LCM, but the peasants are neither the settlor nor the beneficiary of the land trust. In Shaoxing Model, the village economic cooperative made trust contract with trust agent of the town as settlor and in Zhongxin Model the borough government played the role of settlor in the farmland trust. A few problems have emerged in the settlor arrangement in the Chinese farmland trust from the point of view of.

First of all, the interests of peasants decrease because of the agent cost. It's obvious that the "RECO" and the borough government act as the agents of peasants transferring their right to LCM to the trust. In the view of agent cost theory, the agent has different interests from its principal and isn't always acting in principal's best interest. ${ }^{10}$ In the Zhongxin Model, the peasants only received the rents under the contract signed between them and the village committee. But the borough government, being the settlor and beneficiary of the trust, could enjoy extra interests after distributing the rents to the peasants. ${ }^{11}$ The interests of peasants aren't fully protected under the contemporary arrangement of settlor in the land trust.

Secondly, the settlor in the land trust is not fully legally qualified. Under Chinese Trust Law the settlor must use its own property or property rights to set trust. Under current Chinese land institution, "RECO" possess the ownership of the land and the right to LCM belongs to peasants. Borough government is not vested any rights to the rural land. Neither "RECO" nor borough government possesses the right to LCM. Under Measures for the Administration of Circulation of Rural Land Contracted Management Right (Measures for Administration), the assignee of the right to LCM should possess the capacity of agricultural management. ${ }^{12}$ In the Zhongxin Model, the borough government, being the assignee of the right to LCM, didn't have the capacity to conduct any agricultural management. Under Contract Law of People's Republic of China (Contract Law), any contract which violates the compulsory provisions of law and

\footnotetext{
8 It refers to the two rights existing on the farmland, including ownership and right to LCM

9 It refers to the three rights existing on the farmland, including ownership, contracting right and management right.

10 Lucian Bebchuk, Jesse Fried. Pay without Performance: The Unfulfilled Promise of Executive Compensation, Harvard University Press, Massachusetts, 2004, 6-7.

11 Pu Jian. Emancipating the Land: A New Round Reform of Land in Trust Mechanism, China Citic Press, 2014, 233.

12 Article 9 of Measures for the Administration of Circulation of Rural Land Contracted Management Right.
} 
regulation should be null and void. ${ }^{13}$ The trust property is right to LCM or the land management rights, the village committee, town government and borough government are not qualified to be the assignee of the rights. ${ }^{14}$

Thirdly, the peasants transferring their right to LCM will lose the chance to control the trust if they can't take the status of settlor in the land trust. Under Chinese Trust Law, the settlor has the right to know, ${ }^{15}$ the right to adjust the way of management of trust property, ${ }^{16}$ the right to recession, ${ }^{17}$ the right to dismiss trustee, ${ }^{18}$ the right to change beneficiary and distribution of benefits. ${ }^{19}$ Maintaining the rights of settlor in trusts in China lies in three aspects: first, being the provider of trust property, the loss of control of trust property and supervision to trustee doesn't accord with eastern culture tradition; second, it's necessary to vest some rights to settlor in order to protect the interest of unborn and disabled beneficiaries; thirdly, the credit system is not perfect in contemporary China, settlor can exercise the rights to prevent the abuse of trust property by trustee. ${ }^{20}$ The rights of settlor in trusts represent a balance between the settlor and the trustee, which provides the settlor a self-help mechanism against trustee.

Lastly, the fact that "RECO" or government (including government-sponsored entity) takes the status of settlor of land trust diminish the opportunity to disseminate trust conception. With the accumulation of wealth of Chinese people, the need of trust will expand with the dissemination of trust conception among the civil society. The land trust provides a good opportunity for the peasants to get in touch with trust. But the current land trust mechanism excludes the peasants from structure of the trust. Now the "RECO" or the government takes the place of peasants to be settlor, it will lead to the miss of a good opportunity to disseminate the trust conception. If the peasants take the position of settlor of trust, they will get the opportunity to get familiar with the function and operation of trust and trust will find its way of development into the civil life of Chinese people.

\section{B. Trustee}

The appointment of trustee is very important since the trustee not only has the power to decide the beneficial entitlement but also is responsible for the trust administration. ${ }^{21}$ Certain qualification and capacity are

\footnotetext{
13 Ariticle 52 of Contract Law of People's Republic of China Contract Law of People's Republic of China.

14 Jiang Xuelian. Analysis of Legal Issues on Transferring
} Contracted Management Rights of Rural Land by Collective Trust Schemes: Focus on the Trust Plan of Suzhou in Anhui Province Launched by CITIC Trust, Northern Legal Science, No. 4, 2014, 25.

15 Article 20 of Trust Law of People's Republic of China.

16 Article 21 of Trust Law of People's Republic of China.

17 Article 22 of Trust Law of People's Republic of China.

18 Article 23 of Trust Law of People's Republic of China.

19 Article 51 of Trust Law of People's Republic of China.

20 See Zhao Lianhui, Trust Law in China, China Legal Publishing House, 2015, 268-269.

21 Graham Moffat, Gerry Bean and Rebecca Probert, Trust Law, Cambridge University Press, Cambridge, 5th Edition, 2009,420. required for the trustee to manage the trust according to the function and purpose of trust.

There exist several academic concerns about the trustee in Chinese land trust.

The first one is whether trust companies or trust agents which act as trustee in the land trust should meet some legal requirements. Under the Notice of the General Office of the State Council on Issues Concerning the Enforcement of Trust Law of the People's Republic of China after the Promulgation, no legal entities or individuals could take up trust business in any form without the approval of People's Bank or Chinese Security Regulatory Commission before the promulgation of Regulation of Trust Institutions. ${ }^{22}$ Under Measures for the Administration of Trust Company, any institution or individual is prohibited from carrying out trust business and using "trust company" in its name unless they are permitted by China Banking Regulatory Commission $(\mathrm{CBRC})^{23}$

In "Yiyang Model", the local government established trust company which acted as trustee in the land trust. One predicament for trust company in land trust is that "trust company" appears in the name of the company, which violets the mandatory provision of the Measures for the Administration of Trust Company. For the establishment of trust company hasn't got the approval from the CBRC, which leaves the establishment and operation of trust company seemingly illegal. One point of view defending the trust company in "Yiyang Model" points out that the trust company regulated under Regulation of Administration of Trust Company belong to financial institution and should get financial permission certificate before its establishment. But the trust company established by local government just acted as trustee in land trust and it didn't do any financial business. Then trust company in land trust was not necessary to get the approval from the CRBC. ${ }^{24}$

As the trust company in "Yiyang Model" is concerned, it's impossible for the trust company to be established under Measures for the Administration of Trust Company because the rigid requirements are set for the trust company which mainly takes up financial business. The best way out is to make separate regulation for the trust company for the land trust.

Secondly, the roles played by the trustee are significant to the operation of land trust, so the trustee possesses the required capacity provided by relative law is very significant.

In China, there is a strict control on the usages of land, by which the cultivated land is protected specially and rigidly. ${ }^{25}$ The cultivated land can't be use for non-agricultural purpose without approval from the land administration department of

22 Article 2 of Notice of the General Office of the State Council on Issues Concerning the Enforcement of Trust Law of the People's Republic of China after the Promulgation.

23 Article 7 of Measures for the Administration of Trust Company.

24 Zhang Junjian. Research on Trustee Eligibility in Rural Land Contract and Management Rights Transfer, J. CENT. SOUTH UNIV. (SOCIAL SCIENCE) Vol. 21 No. 3, 79, 81.

25 Article 4 of Land Administration Law. 
government. To achieve the goal of the control of the land usages, the Rural Land Contracting Law provides the transferee of the rights to the rural land should possess the agricultural operation capacity. ${ }^{26}$

In "Shaoxin Model", the village economic co-operative trusted the right to LCM to the trust agent of town which took the role of trustee in the trust. But the trust agent was just a circulation service center established by the town government and it didn't have the agricultural operation capacity. So the trust agent is not qualified for the transferee of right to LCM. It's same to the trustee in the "Zhongxin Model". CITIC Trust is a professional financial trust company ${ }^{27}$ established under Measures for the Administration of Trust Companies and is fully qualified for the trust business. But CITIC Trust doesn't possess the capacity to perform agricultural operation and isn't suitable to be the trustee in the land trust under the Rural Land Contracting Law. Some scholar points out that CITIC Trust playing the role of trustee in the land trust will consequently make the land trust null and void. ${ }^{28}$ While the opposite view emphasizes that the requirement of agricultural operation capacity for the professional trust company will hinder its participation and innovation in the farmland trust in China. The provision in the Rural Land Contracting Law that the transferee should possess the agricultural operation capacity should be modified to meet the circulation of farmland. ${ }^{29}$

The purpose of land trust is to facilitate the circulation of land. The trustee could entrust the management and cultivation to others. Whether the transferee possesses the agricultural operation capacity is not critical. The most important is to make the trustee guarantee the agricultural use of the land. To facilitate the operation of the land trust, it should provide some exceptions to the provision in the Land Contracting Law that the transferee should possess the agricultural operation capacity.

The third point is related to the trustee's duty in the land trust. Chinese Trust Law provides that the trustee should handle the trust business personally, but he can entrust an agent to handle the business on his behalf if the trust instrument provides otherwise or he has to do so. ${ }^{30}$ From the provision we can conclude that China Trust Law doesn't acknowledge passive trust. In all the models of land trust in China, none of the trustees takes up the management or the cultivation of the lands. Trustee's main job is to sublet or lease the land to other managers. The main function of trustee is to facilitate the circulation of right to LCM and has no other active duty to perform. One view holds that Chinese land trust practice obviously violates the original intention of

26 Article 33 of Rural Land Contracting Law.

27 Article 2 of Measures for the Administration of Trust Companies.

28 Zhang Junjian. Research on Trustee Eligibility in Rural Land Contract and Management Rights Transfer, J. CENT. SOUTH UNIV. (SOCIAL SCIENCE) Vol. 21 No. 3, 79, 82

29 Liu Guangxiang. Research of Main Legal Issues During Trust Circulation of Right to the Contracted Management of Land - A Case Study of CITIC TRUST Issue of Assembled Rural Land Contracted Management's Trust Plan 1301, Present-day Law Science, Vol. 12 No. 5(2014), 75, 86

30 Article 30 of the Chinese Trust Law. trust institution. ${ }^{31}$ Generally speaking, the trustee must act personally since the settlor chooses trustee for his particular personality, morality or belief. If trustee delegates the administration of trust business to someone else, different value and belief would appear that the settlor wouldn't have wished for. ${ }^{32}$

It's not necessary for the trustee to manage all the trust business personally because no company can do all the work in the modern society. The main function of trust is to maintain and protect the interests of beneficiary by the trustee's management of trust property. In land trust we should focus on what trustee mechanism could maintain the interests of peasants better. In "Yiyang Model" the trustee is a government-sponsored entity which won't involve in the interest division of the land trust while CITIC Trust in "Zhongxin Model" has to make profits for its management since it's a business trust company. But CITIC Trust has much greater capacity to raise fund to support the development of land trust than the trust company in "Yiyang Model". So, some further empirical research should be conducted to demonstrate the advantages and disadvantages of every trustee mechanism.

The last but not the least, the trust agents in "Shaoxin Model" and Trust Corporation in "Yiyang Model" were organized and established by the local government. The government-sponsored entities were not real market player, for they would enforce the intention of government which sometimes contradicted with that of peasants. It would lead to the interference of public authority in the circulation of rights to farmland and confusion of market and government.33 Furthermore, not being the real market player in the market, the participation of government or government-sponsored entity in the land trust will deprive other market players' opportunities to be trustees in the land trust, which in turn causes inefficiency and monopoly in the land trust since the involvement of government. ${ }^{34}$

Being the center of the trust mechanism, the governmentsponsored trustee has neither the agricultural operation capacity and experience nor the common knowledge of trust, although it brings convenience to the circulation of right to LCM. Its existence does no good to the fostering of the sound notion of trust in China, especially in rural area. In other words, if the main role of trustee is to facilitate the circulation of farmland, the trust mechanism is not necessary to adopt, since other institutions also could fulfill the goal of facilitating the circulation of land.

31 XU Wei. Logic Building and Legislation Design for the Model of Collective Trust regarding Land Contract Management Right - A Path Which Accords with Goal of the Land Circulation, Jinan Journal (Philosophy and Social Sciences), Sum No. 193, No. 2, 2015, 50, 58.

32 Richard Edwards and Nigel Stockwell. Trusts and Equity, 7th Edition, 2005, Pearson Education Limited, London, 376.

33 Li Dongxia. On Legal Regulation of Trustee of Rural Land Contractual Management Right, Hebei Law Science, Vol. 33 , No. 93, 96

34 Zhang Zhanfeng. The Role of Government in the Practice of Rights to Contracted Management Land Trust: Samples in Anhui Province and Hunan Province, World Agriculture, Vol. 453, No. 1(2017), 210, 21213. 


\section{Beneficiary}

The trust is created for the interests of the beneficiary. The beneficiary must be sufficiently identifiable in the creation of the trust, since the beneficiary is someone to enforce the trust and ensure that the trustee properly performs his equitable duties. ${ }^{35}$ The Chinese land trust seemingly accords with the certainty of object of trust which needs the sufficient certainty of identity of beneficiaries. But the comprehensive analysis of the beneficiaries of Chinese land trusts will reveal the true predicament that exists in the trust. The trust beneficiary principle just emphasizes the importance of the sufficient certainty of the beneficiaries, but Chinese land trust provides us an opportunity to assess the reasonableness to be a beneficiary.

First of all, the proceeds gotten by the peasants transferring right to LCM were too low to be reasonable. In Yiyang City, the peasants can only get RMB 300(about US\$ 45) more or less for per 0.0667 hectares, ${ }_{37}^{36}$ just one third of the average value of the output of the land. ${ }^{37}$

Secondly, in "Zhongxin Model" and "Shaoxing Model" the peasants transferring their right to LCM don't possess the status of beneficiary of the land trust, which results in the insufficiency in the protection of interests of peasants. In some Chinese land trust models, such as "Zhongxin Model" and "Shaoxing Model", the beneficiaries are the borough government and "RECO" respectively who are actually the agents of peasants. In this arrangement, peasants have neither the statues of settlor nor the status of beneficiary and are excluded from the protection mechanism afforded by the trust law. If their interests are infringed by trustee, what the peasants could do is to assert their rights against the cooperative or village committee, which concludes contract with them as the other party. ${ }^{38}$

Thirdly, if peasants are not the beneficiaries of the land trust, the trustee has no fiduciary duty to them. Chinese Trust Law provides that the trustee has the duty to maintain the best interests of the beneficiary. ${ }^{39}$ In "Shaoxing Model" and "Zhongxing Model", the peasants transferring the right to LCM are neither settlor nor beneficiary of the trust, which implies the peasants do not has control upon the administration of trustee nor does the trustee have duty to maintain the best interests of the peasants for they are not the beneficiaries of the trust. On the other hand, the co-operative, the beneficiary in the "Shaoxin Model" and borough government, the beneficiary in the "Zhongxing Model", got

35 Samantha J Hepburn, Principles of Equity and Trusts Law - 2nd editions (2001), Cavendish Publishing Limited, London, 285.

36 Xie Quenliang. The Circulation Land Trust in the Perspective of Capitalization of Rural Land: Empirical Example of Yiyang, Finance and Economy, No. 9, 2015, 155, 156.

37 The average output of 0.0667 hectare is $770 \mathrm{~kg}$ of rice and the average price was RMB1.3 per kg. see Economic Research Center of Agriculture Minister. Chinese Rural Research Report ( 2012), China Financial and Economic Publishing House, 2013, 62.

38 Jiang Xuelian. Analysis of Legal Issues on Transferring Contracted Management Rights of Rural Land by Collective Trust Schemes: Focus on the Trust Plan of Suzhou in Anhui Province Launched by CITIC Trust, Northern Legal Science, No. 4, 2014, 25, 31.

39 Article 25 of Trust Law of People's Republic of China. the chances to have their best interests maintained by the trustee in the perspective of Chinese Trust Law. The question here is whether the borough government or "RECO" as beneficiary in the trust can guarantee the fulfillment of best interests of the peasants transferring the right to LCM. The answer is obviously no, the intentions and the purposes of co-operative or the borough government is not to maintain and maximize the best interests of peasants transferring the right to LCM. In the "Shaoxin Model", in the circulation of right to LCM by trust in a town named Keping, the peasants got rent of RMB $¥ 189,000$ (about US \$27,794) in total, while the village committee got RMB $¥ 170,000$ (about US\$ 25,000 ) in total by subletting the lands to the contractor. ${ }^{40}$ In "Zhongxin Model", what the peasants could get was only the rent negotiated in the contract between the peasants and village committee, while the borough government, the beneficiary in the land trust, could get extra benefit and remnant benefit of the trust when the trust reached the expiration date after the rents, also called basic interest, were paid to the peasants. ${ }^{41}$

\section{Measures TAKen to Perfect the Chinese LaND TRUST}

From the perspective of institution change theory, the emergence and use of land trust in the transferring the rights to the rural land is the outcome of induced institution change. It has to depend on the profitable opportunities which arise from the institutional disequilibrium such as changes in institutional choices set, technology, relative factors, product prices and other institutional arrangements. ${ }^{42}$ As far as the Chinese land trust is concerned, some innovative institutional arrangement has to be prompted in some aspect.

\section{A. Changing the Status of Peasants in the Land Trust}

By a trust, one can enjoy greater rights, powers and privileges in property ownership without being subject to the liabilities and duties of ownership. ${ }^{43}$ In traditional trust, the settlor is the law-maker who makes the law from which trustee must not deviate. ${ }^{44}$ In another word, trust is a legal tool to maximize the interests on property. In Shaoxing Model and Zhongxing Model the peasants are neither the settlor nor the beneficiary of the land trust and they lose the opportunity to maximize their right to LCM. Their rights and interests cannot be asserted under trust law or trust contract which is more advantageous to them.

As for the beneficiary of the land trust, only the peasants should take the status of beneficiaries although the Chinese

40 Miao Hui, Li Haishen, Zhang Huiling, Some Thoughts on the Establishment of Trust Circulation of Rights to Contracted Management Land, Finance Teaching and Research, Sum. 155, 46, 47.

$41 \quad$ Pu Jian. Emancipating the Land: A New Round Reform of Land by Adoption of Trust, China CITIC Press, Beijing, 2014, 233.

42 Justin Yifu Lin, AN ECONOMIC THEORY OF INSTITUTIONAL CHANGE: INDUCED AND IMPOSED CHANGE, Cato Journal, Vol. 9, No. 1 (Spring/Summer 1989), 14-18

43 Austin W. Scott, The Trust as An Instrument of Law Reform The Yale Law Journal, Vol. 31, No. 5 (Mar., 1922), pp. 457-468, 458.

44 Graham Moffat, Gerry Bean and Rebecca Probert, Trust Law, Cambridge University Press, Cambridge, 5th Edition, 2009,323. 
trust law has no compulsory provision about who should be the beneficiary. ${ }^{45}$ Other bodies rather than peasants, like the village committee, local government, taking the status of beneficiary, will eventually take away certain interest from the peasants. ${ }^{46}$ If the peasants get the status of settlor and beneficiary, the land trust would be peasants friendly for it is more convenient to maintain and the realize of the interests of peasant to the land under Chinese Trust Law.

Perhaps the collective trust is way out of the dilemma. Multi-settlors feature is what Chinese land trust could make reference to. Like investors in the unit trust handing their money to the management of professionals in the trust, peasants transferring their rights to CM Land would like to benefit from joining the land trust. In Yiyang Model, the peasants make trust contract with the trust corporation directly and received benefit and interests as beneficiaries. In Zhongxin Model and Shaoxing Model, the settlor's structure could be improved by unit-trust-like standard trust contract drafted by the trustee of the land trust. Only by doing so, could the idea about what the trust being for and who the trust being for be spread in Chinese civil society properly.

\section{B. Organizational Innovation in Land Trust}

From the experience of business trust and land trust, multi-settlors trust ordinarily takes the form of organization. Land trust in China can take the form of non-profit organization to fulfill its purposes with some advantages.

First, land trust is more easily acceptable to the peasants for its legal existence rather than the strange conception of fiduciary relationship. Most Chinese peasants are not familiar with the concept and mechanism of trust. Trust has been rarely used in civil area, not mentioning the relatively undeveloped rural area.

Secondly, the land trust in organization form is beneficial to the participation of peasants in the management of trust and maintenance of the interests. It's more convenient and practical for the peasants to assert and fulfill their rights and interests in organization mechanism than in an individual peasant's name of settlor or beneficiary.

Thirdly, land trust in the form of organization could minimize the transaction cost. Several decades ago, Coase discovered that the relative price, negotiation and conclusion of contracts mean costs in the price mechanism. The former costs could be reduced within the firm realm. ${ }^{47}$ If a land trust established with the governance of board including peasants, village committee or "RECO", and local government, the costs incurred in concluding contracts between the former parties could be reduced. The reduction of costs is important for the maximizing the interests of the peasants.

$45 \mathrm{Xu}$ Haiyan, Zhang Zhanfeng. The Legal Consideration and Suggestion of Establishing Trust Mode of Land Management Right in China, Law Science Magazine, No.12, 2016, 59, 66.

46 Wu Xingguo, Establish the Rural Land Trust to Resolve the "Sannong" Issue, Journal of Shanghai Economic Management College, No. 3, 2003, 60-64.

47 R. H. Coase, The Nature of the Firm, Economics, New Series, Vol. 4, No. 16. (Nov., 1937), 386, 389-390.

\section{Governmental Support to the Land Trust}

The main purpose of the Chinese land trust is to facilitate the circulation of farmland with the goal to realize the agriculture modernization. From the perspective of economics, the peasants transferring their rights to management of lands to trustee make a positive externality which benefits the nation's scale management and agriculture modernization. In this sense the government should take some measures to make up the contributions the peasants have made.

Because China government has abolished agriculture tax in 2006, tax incentive is no more a useful measure to be taken by the government. Perhaps fiscal subsidy is the most suitable support from the government to spread the use of land trust. The subsidies could be distributed according to the size of farmland transferred to the land trust. The subsidies not only could increase the income of the peasant but also accelerate the spread the land trust to fulfill the goal of agriculture modernization of China.

\section{CONCLUSION}

In some sense, trust originated from the flexible use of land and extended to chattels, such as bonds and securities. The practice of land trust builds out the infrastructure of trust law which formulates the powers of trustee and rights of beneficiary. The main reason that trust has not been fostered well in civil law countries is the absence of practice of trust with land as its trust property. Chinese land trust at least opens a window to disseminate trust conception which is unfamiliar to most people in China.

Now China is facing a good opportunity to extend the conception and practice of land trust. New legislative activity provides more reasonable legal foundation for the land trust. The new policy has divided the right to LCM into contracting right and management right, in which the former persistently belongs to the peasants and the latter can be circulated in various forms. The division of the right to LCM provides more reasonable legal base for the creation and operation of land trust. The transfer of management right to land doesn't influence the peasants' status as the owner of contracting right to land. By land trust the peasants can keep the contracting right to the land while transfers the management right to the trustee and receive some interest form the trustee.

It's the peasants' interests and rights that should be protected and maximized. Without the participation of peasants in the land trust as settlors and beneficiaries, the system discovery function of land trust will diminish. Based on the analysis of the Chinese land trust, "Yiyang Model" land trust is the most reasonable model in China. Being the owner of right to LCM, the peasants take the status of settler and beneficiary of the trust, which makes the structure and operation of the land trust more sustainable in the agricultural context. But the existence and development of land trust in China depends on more factors than the only legal structure of land trust. 
Chinese land trust practice has attracted a lot of concerns both from academic and practical communities. But China has not seen large-scale adoption of land trust throughout the whole country for some limitations. Institution innovations and governmental supports are two crucial elements for the outspread of land trust in Chinese rural areas.

\section{REFERENCES}

[1] Ye Peng, The Development and Trend of Transfer of right to LCM by Farmland Trust, Journal of Northwest A \&F University (Social Science Edition), vol. 16, No. 1, 21, 21.

[2] Shaoxin Fiscal Bureau, Shaoxin County Actively Explore the Mechanism of Land Trust, Rural Finance and Accountant, vol. 9, (2001), 14.

[3] Hu Nengcan, Investigation on Farmland Trust Circulation of "Yiyang Mode" - Practice and Exploration on Farmland Trust Circulation of "Yiyang Mode" in Hunan, Land \& Resource Herald, 2 of vol. 12, 49.

[4] Ye Peng. Development Process and Trend of Farmland Trust Transfer in China, Journal of Northwest A\&F University (Social Science Edition), Vol. 16 No. 1(2016), 22

[5] Professional Trust Corporation in China refers those companies which are established under Trust Law of People's Republic of China and Measures for the Administration of Trust Companies, the trust agents in "Shaoxin" model and land Trust Corporation in "Yiyang" model are not professional trust companies established under former Trust Law and Measures.

[6] Research Group of People's Bank of China Suzhou Sub-branch. Research on the Model of Circulating Trust of Farmland, Financial Perspective Journal, 2015(01), 90.

[7] The General Office of the CPC (Communist Party of China) Central Committee and the General Office of the State Council.

[8] It refers to the two rights existing on the farmland, including ownership and right to LCM.

[9] It refers to the three rights existing on the farmland, including ownership, contracting right and management right.

[10] Lucian Bebchuk, Jesse Fried. Pay without Performance: The Unfulfilled Promise of Executive Compensation, Harvard University Press, Massachusetts, 2004, 6-7

[11] Pu Jian. Emancipating the Land: A New Round Reform of Land in Trust Mechanism, China Citic Press, 2014, 233.

[12] Article 9 of Measures for the Administration of Circulation of Rural Land Contracted Management Right.

[13] Ariticle 52 of Contract Law of People's Republic of China Contract Law of People's Republic of China.

[14] Jiang Xuelian. Analysis of Legal Issues on Transferring Contracted Management Rights of Rural Land by Collective Trust Schemes: Focus on the Trust Plan of Suzhou in Anhui Province Launched by CITIC Trust, Northern Legal Science, No. 4, 2014, 25.

[15] Article 20 of Trust Law of People's Republic of China.

[16] Article 21 of Trust Law of People's Republic of China.

[17] Article 22 of Trust Law of People's Republic of China.

[18] Article 23 of Trust Law of People's Republic of China.

[19] Article 51 of Trust Law of People's Republic of China.

[20] See Zhao Lianhui, Trust Law in China, China Legal Publishing House, 2015, 268-269.

[21] Graham Moffat, Gerry Bean and Rebecca Probert, Trust Law, Cambridge University Press, Cambridge, 5th Edition, 2009,420.

[22] Article 2 of Notice of the General Office of the State Council on Issues Concerning the Enforcement of Trust Law of the People's Republic of China after the Promulgation.

[23] Article 7 of Measures for the Administration of Trust Company.
[24] Zhang Junjian. Research on Trustee Eligibility in Rural Land Contract and Management Rights Transfer, J. CENT. SOUTH UNIV. (SOCIAL SCIENCE) Vol. 21 No. 3, 79, 81 .

[25] Article 4 of Land Administration Law.

[26] Article 33 of Rural Land Contracting Law.

[27] Article 2 of Measures for the Administration of Trust Companies.

[28] Zhang Junjian. Research on Trustee Eligibility in Rural Land Contract and Management Rights Transfer, J. CENT. SOUTH UNIV. (SOCIAL SCIENCE) Vol. 21 No. 3, 79, 82.

[29] Liu Guangxiang. Research of Main Legal Issues During Trust Circulation of Right to the Contracted Management of Land - A Case Study of CITIC TRUST Issue of Assembled Rural Land Contracted Management's Trust Plan 1301, Present-day Law Science, Vol. 12 No. 5(2014), 75, 86

[30] Article 30 of the Chinese Trust Law.

[31] XU Wei. Logic Building and Legislation Design for the Model of Collective Trust regarding Land Contract Management Right - A Path Which Accords with Goal of the Land Circulation, Jinan Journal (Philosophy and Social Sciences), Sum No. 193, No. 2, 2015, 50, 58.

[32] Richard Edwards and Nigel Stockwell. Trusts and Equity, 7th Edition, 2005, Pearson Education Limited, London, 376.

[33] Li Dongxia. On Legal Regulation of Trustee of Rural Land Contractual Management Right, Hebei Law Science, Vol. 33 , No. 93, 96

[34] Zhang Zhanfeng. The Role of Government in the Practice of Rights to Contracted Management Land Trust: Samples in Anhui Province and Hunan Province, World Agriculture, Vol. 453, No. 1(2017), 210, 21213 .

[35] Samantha J Hepburn, Principles of Equity and Trusts Law - 2nd editions (2001), Cavendish Publishing Limited, London, 285.

[36] Xie Quenliang. The Circulation Land Trust in the Perspective of Capitalization of Rural Land: Empirical Example of Yiyang, Finance and Economy, No. 9, 2015, 155, 156

[37] The average output of 0.0667 hectare is $770 \mathrm{~kg}$ of rice and the average price was RMB1.3 per kg. see Economic Research Center of Agriculture Minister. Chinese Rural Research Report ( 2012 ), China Financial and Economic Publishing House, 2013, 62.

[38] Jiang Xuelian. Analysis of Legal Issues on Transferring Contracted Management Rights of Rural Land by Collective Trust Schemes: Focus on the Trust Plan of Suzhou in Anhui Province Launched by CITIC Trust, Northern Legal Science, No. 4, 2014, 25, 31.

[39] Article 25 of Trust Law of People's Republic of China.

[40] Miao Hui, Li Haishen, Zhang Huiling, Some Thoughts on the Establishment of Trust Circulation of Rights to Contracted Management Land, Finance Teaching and Research, Sum. 155, 46, 47

[41] Pu Jian. Emancipating the Land: A New Round Reform of Land by Adoption of Trust, China CITIC Press, Beijing, 2014, 233.

[42] Justin Yifu Lin, AN ECONOMIC THEORY OF INSTITUTIONAL CHANGE: INDUCED AND IMPOSED CHANGE, Cato Journal, Vol. 9, No. 1 (Spring/Summer 1989), 14-18.

[43] Austin W. Scott, The Trust as An Instrument of Law Reform, The Yale Law Journal, Vol. 31, No. 5 (Mar., 1922), pp. 457-468, 458.

[44] Graham Moffat, Gerry Bean and Rebecca Probert, Trust Law, Cambridge University Press, Cambridge, 5th Edition, 2009,323.

[45] Xu Haiyan, Zhang Zhanfeng. The Legal Consideration and Suggestion of Establishing Trust Mode of Land Management Right in China, Law Science Magazine, No.12, 2016, 59, 66.

[46] Wu Xingguo, Establish the Rural Land Trust to Resolve the "Sannong" Issue, Journal of Shanghai Economic Management College, No. 3, 2003, 60-64.

[47] R. H. Coase, The Nature of the Firm, Economics, New Series, Vol. 4 No. 16. (Nov., 1937), 386, 389-390. 